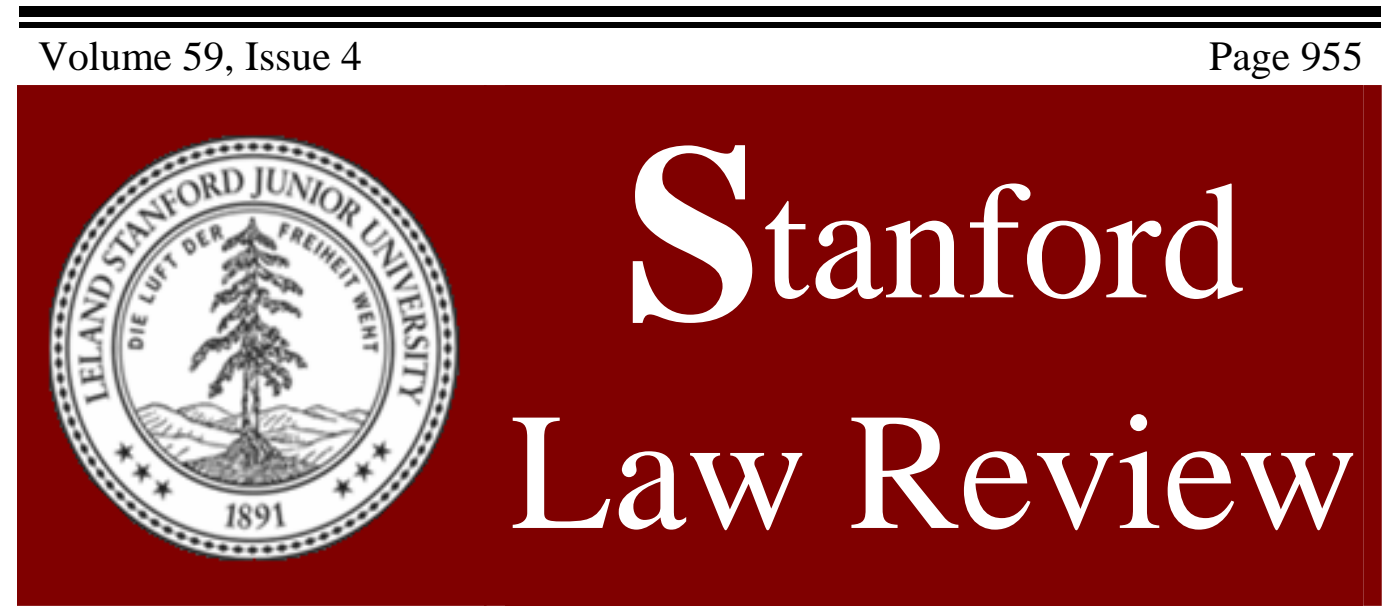

\title{
THE (UNNOTICED) DEMISE OF THE DOCTRINE OF EQUIVALENTS
}

John R. Allison

Mark A. Lemley

(C) 2007 by John R. Allison, Mark A. Lemley, the Board of Trustees of the Leland Stanford Junior University, from the Stanford Law Review at 59 STAN. L. REV. 955 (2007). For information visit http://lawreview.stanford.edu. 


\title{
THE (UNNOTICED) DEMISE OF THE DOCTRINE OF EQUIVALENTS
}

\author{
John R. Allison* and Mark A. Lemley*

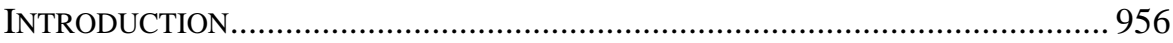

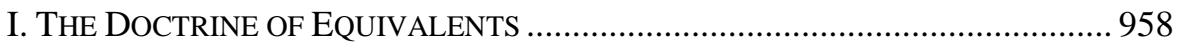

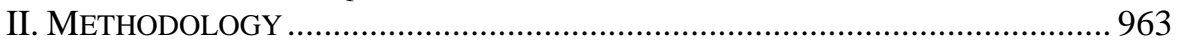

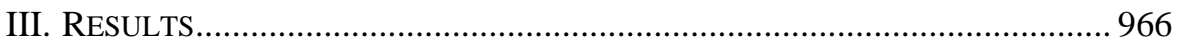 \\ A. Patentees Rarely Win............................................................................ 966 \\ B. Do the Legal Rules Matter?................................................................... 968 \\ C. Other Findings ......................................................................................... 970 \\ 1. Learning effects in the district courts ............................................ 970 \\ 2. Who uses the doctrine of equivalents?.............................................. 972

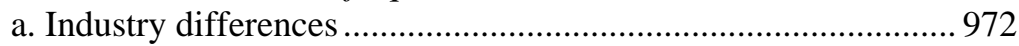

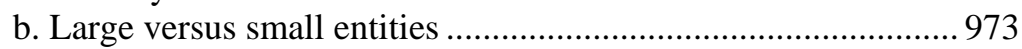 \\ 3. What arguments prevail?................................................................... 974 \\ 4. Does case publication matter? ……………………........................... 976

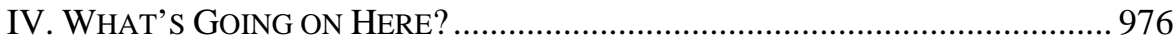

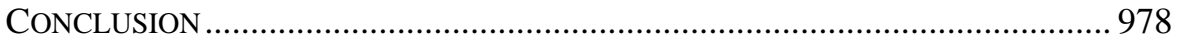

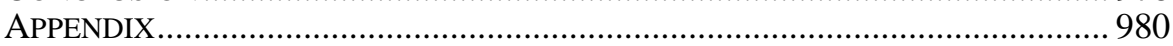

(C) 2007 by John R. Allison, Mark A. Lemley, and the Board of Trustees of the Leland Stanford Junior University.

* Spence Centennial Professor, McCombs School of Business, University of Texas at Austin.

** William H. Neukom Professor, Stanford Law School; of counsel, Keker \& Van Nest LLP.

We are particularly grateful to Michael Martin, who spent a great deal of time identifying the three primary datasets of cases used in our study, and Sarah Craven, Ph.D., who did additional work on those datasets and developed the fourth. We also thank Dan Lin, Ph.D., and Daniel Lee, Ph.D., for their statistical analysis; Nancy Heger, Ph.D., and Starling Hunter, Ph.D., for statistical advice; Jim Hirabayashi of the PTO for providing small entity data; Paul Janicke for providing us with Rule 36 data from his ipstats.org database; and Rose Hagan, Dan Ho, Tim Holbrook, Josh Lerner, Ronald Mann, Craig Nard, and participants in the Works in Progress/IP conference at the University of Pittsburgh Law School for comments on an earlier draft. Each author blames the other for any errors in the Article. 


\section{INTRODUCTION}

Patent lawyers, courts, and scholars have spent an enormous amount of time and energy over the last twenty-five years trying to determine the rationale and scope of the doctrine of equivalents, an exception to normal patent infringement rules that allows patent owners to extend the scope of patents beyond their literal bounds in certain circumstances. ${ }^{1}$ Judges and scholars in the late 1990s suggested that the doctrine of equivalents exception was swallowing the rule, ${ }^{2}$ complained that it "lacks a coherent vision" and labeled it the most controversial doctrine in all of patent law. ${ }^{3}$ Two of the three most important Supreme Court patent cases decided between 1981 and 2005 concerned the scope of a limitation on the doctrine of equivalents called prosecution history estoppel. ${ }^{4}$ The Festo case in particular whipped the patent

1. For significant scholarship on the doctrine of equivalents, see, for example, Charles W. Adams, The Doctrine of Equivalents: Becoming a Derelict on the Waters of Patent Law, 84 Neb. L. Rev. 1113 (2006); Martin J. Adelman \& Gary L. Francione, The Doctrine of Equivalents in Patent Law: Questions that Pennwalt Did Not Answer, 137 U. PA. L. Rev. 673 (1989); Matthew J. Conigliaro et al., Foreseeability in Patent Law, 16 BERKELEY TeCH. L.J. 1045 (2001); Christopher A. Cotropia, “After-Arising” Technologies and Tailoring Patent Scope, 61 N.Y.U. ANN. SuRV. AM. L. 151 (2005); Timothy R. Holbrook, Possession in Patent Law, 59 SMU L. Rev. 123, 164-69 (2006); Doug Lichtman, Substitutes for the Doctrine of Equivalents: A Response to Meurer and Nard, 93 GEO. L.J. 2013 (2005); Robert P. Merges \& Richard R. Nelson, On the Complex Economics of Patent Scope, 90 Colum. L. Rev. 839 (1990); Michael J. Meurer \& Craig Allen Nard, Invention, Refinement, and Patent Claim Scope: A New Perspective on the Doctrine of Equivalents, 93 GEO. L.J. 1947 (2005); Paul R. Michel, The Role and Responsibility of Patent Attorneys in Improving the Doctrine of Equivalents, 40 IDEA 123 (2000); S. Jay Plager, Challenges for Intellectual Property Law in the Twenty-First Century: Indeterminacy and Other Problems, 2001 U. ILL. L. REV. 69; Joshua D. Sarnoff, Abolishing the Doctrine of Equivalents and Claiming the Future After Festo, 19 BERKELEY TECH. L.J. 1157 (2004); Brian J. Teague, Festo and the Future of the Doctrine of Equivalents, 3 CHI.-Kent J. INTELl. Prop. 1 (2003); John R. Thomas, Claim Reconstruction: The Doctrine of Equivalents in the Post-Markman Era, 9 LEWIS \& CLARK L. REV. 153 (2005); R. Polk Wagner, Reconsidering Estoppel: Patent Administration and the Failure of Festo, 151 U. PA. L. REV. 159 (2002); Harold C. Wegner et al., The Future of the Doctrine of Equivalents, 26 AIPLA Q.J. 277 (1998); Alan L. Durham, Patent Symmetry (2006) (unpublished manuscript, on file with authors).

2. See, e.g., Meurer \& Nard, supra note 1; Michel, supra note 1; Sarnoff, supra note 1.

3. Meurer \& Nard, supra note 1 , at 1948-49.

4. Festo Corp. v. Shoketsu Kinzoku Kogyo Kabushiki Co., 535 U.S. 722 (2002); Warner-Jenkinson Co. v. Hilton Davis Chem. Co., 520 U.S. 17 (1997). The doctrine of prosecution history estoppel prevents patent owners from seeking to capture ground under the doctrine of equivalents that they gave up during the process of obtaining the patent, either by amending the patent claims to narrow their scope or by representing to the Patent and Trademark Office (PTO) that the claims did not cover a particular technology. For a fuller description, see infra notes 26-40 and accompanying text.

The other important case during this period is Markman $v$. Westview Instruments, Inc., 517 U.S. 370 (1996), which held that claim construction is a matter of law, not fact. Cases in 2006 and 2007 are arguably more significant for patent law. eBay, Inc. v. MercExchange, L.L.C., 126 S. Ct. 1837 (2006) (holding injunctions in patent cases should not be automatic but should be based on traditional principles of equity); Teleflex, Inc. v. KSR Int'l Co., 119 
bar into an unprecedented frenzy, attracting more amicus briefs than any other Supreme Court patent case up to that date. ${ }^{5}$

The Festo case also created a perfect natural test for the importance of patent rules on case outcomes. Before the Federal Circuit's en banc decision in Festo, courts often took a relatively permissive (that is, patent-friendly) stance towards prosecution history estoppel by allowing patent owners to capture ground in court they had unnecessarily given up in patent prosecution. ${ }^{6}$ In 2000, the Federal Circuit en banc reversed course, creating an absolute bar against applying the doctrine of equivalents to an element in a patent claim where the patentee had narrowed that element in the course of obtaining the patent. $^{7}$ Two years later, the Supreme Court reversed course again, taking a middle ground by creating a presumption that such narrowing of a patent in the PTO creates estoppel, but allowing that presumption to be rebutted in various circumstances. ${ }^{8}$ To many patent lawyers, the Supreme Court saved patent law from catastrophe by reversing the absolute bar. ${ }^{9}$

We have conducted an empirical study of every reported doctrine of equivalents decision in both the Federal Circuit and the district courts during three periods - one before the Federal Circuit's 2000 Festo opinion, one after that opinion but before the Supreme Court's 2002 opinion, and a third after the Supreme Court's opinion. We report a number of results that will be of interest to both scholars and patent lawyers. Two broader findings stand out in the data that should be of interest to the legal system more generally. First, the multiple changes in the doctrine of equivalents rules over the last ten years have had surprisingly little effect on the actual outcome of doctrine of equivalents cases, and even less effect on the subset of cases dealing directly with prosecution history estoppel. Indeed, to the extent there is any relationship it is an inverse one-patentees did better under less patent-friendly rules. The attention everyone has paid to Festo as changing the value of patent rights therefore

F. App’x 282 (Fed. Cir. 2005), cert. granted, 126 S. Ct. 2965 (June 26, 2006) (presenting the question of when prior art should be combined for the purpose of determining whether a patent is invalid because of obviousness).

5. Twenty-seven different amicus briefs were filed on the merits before the Supreme Court by parties representing a wide range of interests. The record was eclipsed in 2006 by the $e$ Bay case, which attracted thirty-one amicus briefs.

6. See, e.g., Insituform Techs., Inc. v. CAT Contracting, Inc., 156 F.3d 1199 (Fed. Cir. 1998). This decision was ultimately reversed under the new standard of Festo. Insituform Techs., Inc. v. CAT Contracting, Inc., 385 F.3d 1360 (Fed. Cir. 2004).

7. Festo Corp. v. Shoketsu Kinzoku Kogyo Kabushiki Co., 234 F.3d 558 (Fed. Cir. 2000) (en banc), vacated by 535 U.S. 722 (2002).

8. Festo, 535 U.S. 722.

9. See, e.g., Jenny B. Davis, Facing Up to Festo, A.B.A. J., July 2002, at 30; Barbara E. Johnson \& David C. Hanson, A Practical Guide to the Festo Decision, Prac. LAW., Feb. 2003, at 47. But see Adams, supra note 1, at 1149-52 (suggesting that the Supreme Court decision presages a coming decline in the doctrine); Kenneth D. Bassinger, Unsettled Expectations in Patent Law: Festo and the Moving Target of Claim Equivalence, 48 HOWARD L.J. 685, 686 (2005) (same). 
seems to have been largely wasted from a practical perspective. The result is an interesting case study on "law in action" and how it can diverge from law on the books.

The second finding is even more significant: the reason the Festo changes had so little effect seems to be that the doctrine of equivalents was already near death by the late 1990s. Even under the relatively permissive doctrine of equivalents rules in place before 2000, equivalents claims usually failed, most often on summary judgment. That became even more true after 2000, and the Supreme Court's 2002 decision didn't change the trend. In fact, district courts are more likely to reject doctrine of equivalents claims today than ever before.

This left us with a bit of a puzzle: what killed the doctrine of equivalents in the 1990s? We suspected the answer was the growth of claim construction "Markman" hearings after the Supreme Court's 1996 decision in that case. Once courts were construing claims as a matter of law pre-trial, and finding themselves in a position to resolve virtually all infringement issues on summary judgment, they were naturally inclined to decide the doctrine of equivalents issues too. And a court that has just rejected a literal infringement argument - the only kind of court likely to spend much time thinking about equivalents issues pre-trial-is unlikely to undo the work of claim construction by sending the issue of infringement by equivalents to the jury. To test this hypothesis, we constructed a fourth dataset, including cases decided in the 1993 to 1995 timeframe. That dataset bears out our hypothesis. The doctrine of equivalents was alive and well before Markman, but has been in decline ever since.

In Part I, we explain the doctrine of equivalents, prosecution history estoppel, and the changes in the law that have occurred during the last ten years. Part II sets out the details of our study. In Part III, we report our findings. Finally, Part IV draws some broader conclusions and investigates what caused the unexpectedly early-and largely unnoticed-demise of the doctrine of equivalents.

\section{THE DOCTRINE OF EQUIVALENTS}

The goal of the patent system is to encourage innovation. Patents do this by giving the first inventor of a new and nonobvious technology the exclusive right to make, use, and sell the patented invention. ${ }^{10} \mathrm{~A}$ patent owner's rights are defined not by what the patentee built - they may not have built anythingbut by the patent claims, which courts liken to the "metes and bounds" of a real property deed. ${ }^{11}$ A user literally infringes a patent if, but only if, she includes

10. 35 U.S.C. $\S 271$ (a) (2007). More precisely, the patent right is a negative one-the right to exclude others from making, using, selling, offering to sell, or importing the patented invention.

11. See, e.g., In re Vamco Mach. \& Tool, Inc., 752 F.2d 1564, 1577 n.5 (Fed. Cir. 
each and every element of the patent claims in her product. ${ }^{12}$ Courts recognized quite early in patent history, however, that a too-strict application of this rule would make it trivial to evade many patents by making insubstantial changes to one piece of the invention. This may be true either because the patent owner did not do a perfect job of anticipating and including changes that might be made to the invention by others ${ }^{13}$ or because changed circumstances or laterdeveloped technologies make possible variations the patentee could not have foreseen. ${ }^{14}$ Courts can address these imperfections with the doctrine of equivalents, which effectively expands patent claims beyond their literal scope to devices that are not very different from the patented invention. ${ }^{15}$

Such an expansion requires courts to define what differences are insubstantial enough that they should be considered infringing, lest the doctrine of equivalents swallow the rule that patent claims define the scope of the invention. Courts have developed a number of tests for applying the doctrine of equivalents. The most commonly applied test, which fits mechanical inventions particularly well but which is also applied to other kinds of subject matter, is the "function-way-result" test. This tripartite test finds equivalence only if the defendant's product performs substantially the same function in substantially the same way to achieve the same result. ${ }^{16}$ Other cases have applied a more general "insubstantial differences" approach, asking how different the defendant's product is from the patent claims. ${ }^{17}$ Courts also ask-or at least they used to ask - whether the patent covers a pioneering invention that should be entitled to a greater scope of protection. ${ }^{18}$ Courts also emphasize that each

1985). In Judge Rich's famous words, "the name of the game is the claim.” Giles S. Rich, Extent of Protection and Interpretation of Claims-American Perspectives, 21 INT'L REV. INDUS. PROP. \& COPYRIGHT L. 497, 499 (1990).

12. London v. Carson Pirie Scott \& Co., 946 F.2d 1534, 1538-39 (Fed. Cir. 1991).

13. As the Supreme Court recognized in Festo, perfect claim drafting may be impossible: "Unfortunately, the nature of language makes it impossible to capture the essence of a thing in a patent application.” Festo, 535 U.S. at 731.

14. Sage Prods., Inc. v. Devon Indus., Inc., 126 F.3d 1420 (Fed. Cir. 1997); Conigliaro et al., supra note 1 , at 1045 .

15. Graver Tank \& Mfg. Co. v. Linde Air Prods. Co., 339 U.S. 605 (1950); Hilton Davis Chem. Co. v. Warner-Jenkinson Co., 62 F.3d 1512 (Fed. Cir. 1995) (en banc), rev'd on other grounds, 520 U.S. 17 (1997).

16. Graver Tank, 339 U.S. at 608.

17. Hilton Davis, 62 F.3d at 1517.

18. See, e.g., Miller v. Eagle Mfg. Co., 151 U.S. 186, 207 (1894) ("If the invention is broad or primary in its character, the range of equivalents will be correspondingly broad, under the liberal construction which the courts give to such inventions.”); Perkin-Elmer Corp. v. Westinghouse Elec. Corp., 822 F.2d 1528, 1532 (Fed. Cir. 1987) (“A pioneer invention is entitled to a broad range of equivalents.”); John R. Thomas, The Question Concerning Patent Law and Pioneer Inventions, 10 High TECH. L.J. 35, 37 (1995) ("Courts construe pioneer patent claims ... to encompass a broader range of so-called 'equivalents' during an infringement determination."). The doctrine today may or may not be moribund, though it is clearly applied only infrequently by the Federal Circuit. Compare Augustine Med., Inc. v. Gaymar Indus., Inc., 181 F.3d 1291, 1301 (Fed. Cir. 1999) (relying on 
and every element of the patent claim must be present in the accused device either literally or by equivalence. ${ }^{19}$ This "all elements" test prevents a finding of infringement if even one element is entirely missing. It also prevents the patentee from using the doctrine of equivalents to so broaden a claim element that it would vitiate it entirely. ${ }^{20}$

In addition to defining the scope of the doctrine of equivalents, courts have also created a number of limitations on the doctrine. ${ }^{21}$ First, they will not use the doctrine of equivalents to expand the claims to such an extent that they read on the "prior art"-the universe of things others had done before the invention. ${ }^{22}$ Since a patent applicant could not write a valid patent claim that would literally cover the prior art, ${ }^{23}$ courts quite logically have concluded that patent owners cannot achieve the same result by applying the doctrine of equivalents. Second, the Federal Circuit adopted in 2002 a doctrine called "dedication to the public domain," under which a patent owner cannot capture under the doctrine of equivalents any technological equivalent that was disclosed in the patent but not claimed. ${ }^{24}$ The court reasoned that since the doctrine of equivalents was designed to protect patent owners against unanticipated uses, it should not apply where the patent owner did (or at least reasonably could have) anticipated the use. ${ }^{25}$

The final limitation on the doctrine of equivalents, and the one that has created the most controversy, is the doctrine of prosecution history estoppel. Prosecution history estoppel arises when the patentee obtains her patent by making certain representations to the PTO about the limited scope of the patent and then seeks to use the doctrine of equivalents to expand the scope of those

“pioneering” standard), with Sun Studs, Inc. v. ATA Equip. Leasing, Inc., 872 F.2d 978, 987 (Fed. Cir. 1989) (referring to the pioneer patents rule as "ancient jurisprudence").

19. Warner-Jenkinson Co. v. Hilton Davis Chem. Co., 520 U.S. 17, 29 (1997); Pennwalt Corp. v. Durand-Wayland, Inc., 833 F.2d 931 (Fed. Cir. 1987) (en banc), abrogated on other grounds by Cardinal Chem. Co. v. Morton Int'l, Inc., 508 U.S. 83 (1993).

20. See, e.g., Primos, Inc. v. Hunter’s Specialties, Inc., 451 F.3d 841, 850 (Fed. Cir. 2006). For this reason, it is also reasonable to think of it as a limitation on the doctrine rather than a test for applying it. Because the all elements rule is formulated as a test for equivalence, rather than as an exclusion of claims otherwise found to be equivalent, we have treated it with the other tests rather than with the defenses. But we don't believe that the characterization matters much.

21. For a concise summary of these limitations, see Holbrook, supra note 1, at 164-69.

22. See Wilson Sporting Goods Co. v. David Geoffrey \& Assocs., 904 F.2d 677 (Fed. Cir. 1990), abrogated on other grounds by Cardinal Chem. Co. v. Morton Int'l, Inc., 508 U.S. 83 (1993).

23. 35 U.S.C. $\S 102$ (2007).

24. Johnson \& Johnston Assocs. Inc. v. R.E. Serv. Co., 285 F.3d 1046 (Fed. Cir. 2002) (en banc).

25. See, e.g., SciMed Life Sys., Inc. v. Advanced Cardiovascular Sys., Inc., 242 F.3d 1337 (Fed. Cir. 2001); see also Timothy R. Holbrook, Substantive Versus Process-Based Formalism in Claim Construction, 9 LEWIS \& CLARK L. REV. 123, 139 (2005) (referring to this as "specification estoppel”). 
rights. Sometimes those representations occur by argument: the patentee persuades the PTO to grant a patent over a piece of prior art by explaining to the Examiner how the patent differs from the prior art. Even if the patentee did not need to make such an argument to distinguish her invention from the prior art, prosecution history estoppel stems from the belief that the Examiner should get to make that judgment in the first instance. An applicant who tells the PTO her patent covers only a certain ground should be stuck with that representation. $^{26}$ Something similar occurs when a patentee amends her claims to narrow them in order to avoid the prior art. If the patentee gives up ground in order to persuade the PTO to issue the patent, the rationale of prosecution history estoppel is that she should not be able to recapture that ground in court. $^{27}$

The question then becomes what precisely a patent owner gave up by amending her claims. In Warner-Jenkinson, for example, Hilton Davis claimed an ultrafiltration system for purifying dyes. ${ }^{28}$ The PTO rejected the application on the basis of a prior invention by Booth, who had already developed an ultrafiltration system that used the same temperature, pressure, and filter pore size. The patent owner amended the claims to limit its system to operate at a $\mathrm{pH}$ from approximately 6.0 to 9.0 (on a scale of 0 to 14). This served to distinguish the Booth patent, which claimed a process that operated at a $\mathrm{pH}$ of 9.0 to $13.0 .^{29}$ There is no question that Hilton Davis could not use the doctrine of equivalents to cover a defendant's system operating at a $\mathrm{pH}$ of above 9.0; doing so would expand the claim so far that it covered the prior art. But how about a pH of 5.0, which was just below the Hilton Davis patent's lower limit and at which the process of Warner-Jenkinson, the accused infringer, operated ${ }^{30}$ In Warner-Jenkinson, the Court held that where a patentee did not explain why it introduced a limitation (here, the $6.0 \mathrm{pH}$ lower limit), the Court would presume that the new limitation was necessary to obtain the patent, and therefore deny doctrine of equivalents protection for that element. ${ }^{31}$ The Court left open the possibility that the presumption could be rebutted, however. ${ }^{32}$

After the Supreme Court's 1997 decision in Warner-Jenkinson, the Federal Circuit generally permitted patentees to apply the doctrine of equivalents to

26. However, the Federal Circuit has of late limited estoppel by argument claims, requiring a "clear and unmistakable surrender" of subject matter, a test seemingly imported from the claim construction cases. See, e.g., Abraxis Bioscience, Inc. v. Mayne Pharma (USA) Inc., 467 F.3d 1370, 1381 (Fed. Cir. 2006).

27. For an argument for abolishing the doctrine outright, see John R. Thomas, On Preparatory Texts and Proprietary Technologies: The Place of Prosecution Histories in Patent Claim Interpretation, 47 UCLA L. REV. 183 (1999) (suggesting destroying the prosecution history after a patent issues).

28. Warner-Jenkinson Co. v. Hilton Davis Chem. Co., 520 U.S. 17, 21 (1997).

29. Id. at 32.

30. Id. at 23.

31. Id. at 33.

32. Id. 
reclaim some technological territory that it had surrendered during patent examination, if it could demonstrate that it did not need to give up the ground in question. ${ }^{33}$ We refer to this approach as the "flexible bar" because it allowed the patent owner to recapture ground it unnecessarily gave up. In 2000, though, the Federal Circuit decided Festo en banc. ${ }^{34}$ There, the court held that when a patentee amended a claim so as to narrow its technological reach, the patentee relinquished any right to use the doctrine of equivalents for the particular claim element that had been narrowed. The decision came as a great shock to the patent bar, prompting not only vigorous dissents by four judges ${ }^{35}$ but amicus briefs $^{36}$ and articles ${ }^{37}$ challenging the decision. This "absolute bar" rule was the law until 2002, when the Supreme Court reversed the Federal Circuit's Festo decision. ${ }^{38}$ Rather than revert to the flexible bar, however, the Court maintained the general Federal Circuit rule that a narrowing amendment for any reason related to patentability triggered estoppel, but created two exceptions to that general rule. Recognizing the difficulty in writing patent claims that map perfectly to inventions, ${ }^{39}$ the Court held that estoppel should not apply, and the doctrine of equivalents could still be used, where the effect of the amendment was unforeseeable at the time it was made ${ }^{40}$ or where its

33. See, e.g., Insituform Techs., Inc. v. CAT Contracting, Inc., 156 F.3d 1199 (Fed. Cir. 1998). For example, had the prior art Booth patent in Warner-Jenkinson operated at a $\mathrm{pH}$ of 10, this approach would have allowed the patentee to use the doctrine of equivalents to cover processes that operated at a $\mathrm{pH}$ of 9.5, reasoning that even if the patentee had given up this ground during prosecution, he did not need to do so in order to distinguish the prior art.

34. Festo Corp. v. Shoketsu Kinzoku Kogyo Kabushiki Co., 234 F.3d 558 (Fed. Cir. 2000) (en banc), vacated by 535 U.S. 722 (2002).

35. Id. at 598-619 (Michel, J., concurring in part, dissenting in part); id. at 619-20 (Rader, J., concurring in part, dissenting in part); id. at 620-29 (Linn, J., concurring in part, dissenting in part); id. at 630-42 (Newman, J., concurring in part, dissenting in part).

36. See supra note 5 (discussing amicus briefs).

37. See, e.g., Conigliaro et al., supra note 1 (criticizing the Federal Circuit's absolute bar rule and calling for application of a foreseeable bar rule that was later adopted by the Supreme Court); Rochelle K. Seide \& Carmella L. Stephens, Drafting Claims for Biotechnology Inventions, 730 PLI/PAT 469, 546 (2002) (stating that the Federal Circuit's absolute bar rule was "inconsistent with prior case law”); Conrad J. DeWitte, Jr., Comment, Festo Change-O? No Way! Why the Supreme Court Should Reverse the Federal Circuit's Attack on the Doctrine of Equivalents, 51 CATH. U. L. REV. 1323 (2002) (arguing against the Federal Circuit's absolute bar rule and in favor of a flexible bar rule).

38. Festo Corp. v. Shoketsu Kinzoku Kogyo Kabushiki Co., 535 U.S. 722 (2002).

39. Id. at 731 .

40. Id. at 740. By "effect of the amendment was unforeseeable at the time it was made," we mean that the equivalent element in the accused infringer's product would not have been a foreseeable equivalent to the counterpart element in the patentee's asserted claim at the time the narrowing amendment was made. Unforeseeable to whom, however, is not a question on which the Court was entirely clear. On remand, the Federal Circuit held that the effect of the amendment must be unforeseeable, not just to the person who made the change (a subjective standard), but to the person having ordinary skill in the art (PHOSITA), a hypothetical construct who is presumed to be aware of all the prior art. Festo Corp. v. Shoketsu Kinzoku Kogyo Kabushiki Co., 344 F.3d 1359 (2003). 
purpose was merely tangential to the effect it was now alleged to have. ${ }^{41}$ Since 2002 this "foreseeable bar" has been the rule.

\section{METHODOLOGY}

We took advantage of this unique change in the legal rules to study how changes in the law affected the doctrine of equivalents. To do this, we collected every district court and court of appeals decision on the doctrine of equivalents that appeared in Westlaw ${ }^{42}$ and was decided during three eighteen-month periods: one before the first Federal Circuit Festo decision (including every case decided between May 28, 1999 and November 28, 2000), one after the Federal Circuit but before the Supreme Court Festo decision (including every case decided between December 6, 2000 and May 27, 2002), and one after the Supreme Court decision (including every case decided between February 27, 2004 and August 31, 2005). ${ }^{43}$ The result is a total of 413 decisions, 196 from the Federal Circuit and 217 from the district courts. ${ }^{44}$ The universe of all decisions is of course different from the universe of those reported in Westlaw, and in particular our study underreports jury decisions. But our focus on written decisions (both reported and unreported) allows us to parse the grounds

41. Festo, 535 U.S. at 740. The Court also suggested that there might be "some other reason” why an amendment shouldn’t create an estoppel. Id. at 741. The Federal Circuit held on remand that that suggestion would be construed narrowly and would not constitute a separate ground for avoiding estoppel. Festo, 344 F.3d at 1370. And the Federal Circuit has read the "tangential" limitation narrowly as well. See Amgen, Inc. v. Hoechst Marion Roussel, Inc., 457 F.3d 1293, 1313-15 (Fed. Cir. 2006).

42. Specifically, we identified every case that included the term "equivalents" or "doctrine of equivalents," a total of approximately 1200 cases. Many of these cases, however, did not in fact involve resolution of a doctrine of equivalents question, and thus we limited the universe to cases that also included citations to Graver Tank, Warner-Jenkinson, or Festo or the phrase "file wrapper estoppel" or "prosecution history estoppel." Our research assistant, Michael Martin, closely studied those cases to identify those in which there was actually a decision on application of the doctrine of equivalents.

43. We used three eighteen-month periods because this was the amount of time that elapsed between the Federal Circuit and Supreme Court decisions in Festo, and we believed that it was desirable to use equal time periods. Also, we chose to not begin the last period immediately after the Supreme Court decision, but to capture a somewhat later eighteenmonth period after both district courts and the Federal Circuit had more time to fully absorb changes in the doctrine of equivalents legal regime over the entire relevant period. Throughout this Article we refer to the three time periods in either of two ways: (1) "preFesto, Fed.Cir. Festo, and post-Supreme Court Festo"; or (2) "pre-Festo, mid-Festo, and post-Festo."

44. We define a decision as the most recent ruling on the doctrine of equivalents with respect to a particular patent. If a decision is later reversed, affirmed, or superseded, we report the most recent decision (assuming it is within our time parameters), and not the previous one. In this way we avoid "double-counting" a case. Some cases generate multiple "decisions" under our definition because they involve doctrine of equivalents rulings on multiple patents. In a few cases, the court issued different doctrine of equivalents decisions on separate claims within the same patent. In these cases we treated each such separate ruling as a separate decision. 
for decision and the reasoning of the opinions. We also distinguished between published and unpublished decisions in order to learn whether the decision to publish an opinion is significantly related to the outcome of the case.

For each decision, we collected a wide range of data. For the core of our study, we first collected a variety of data on the courts' decisions on the doctrine of equivalents. We determined whether the patentee won on the issue before the court, and at which procedural stage. This does not always mean that they won the case, but rather that they may have defeated a motion for summary judgment and were able to proceed to trial, or got an adverse ruling reversed. We determined whether the court applied the "function-way-result" test, the "insubstantial differences" test, or the "all elements rule" (or, as often happened, more than one such rule) in deciding the doctrine of equivalents issue. ${ }^{45}$ We also determined whether the court considered either the doctrine of dedication to the public domain or prosecution history estoppel as a limitation on the doctrine of equivalents, who won on that issue, and for prosecution history estoppel whether the estoppel was based on argument or amendment. ${ }^{46}$ Finally, we identified those cases that involved doctrine of equivalents analysis of so-called "means-plus-function" claims, a doctrine that allows structural limitations to be claimed by their function. ${ }^{47}$ We also collected data on the case itself-the court in which it appeared, the procedural posture of the case, and (if the decision was on summary judgment or judgment as a matter of law) who filed the motion.

Second, we collected a variety of data on the patents that were at issue in these disputes. We hand-categorized each patent into one or more of fourteen different technology areas in order to determine whether there are industryspecific differences in the use of the doctrine of equivalents, ${ }^{48}$ and determined

45. We found a sizeable number of cases in which the court refused to apply the doctrine of equivalents because doing so would "vitiate a claim element." We classed such cases with the "all elements" rule, on the theory that the court was ruling that the plaintiff's doctrine of equivalents contention would not ensure that there was an equivalent for each and every element. The "vitiation" language came into vogue contemporaneously with the period of our study - the first Federal Circuit reference to it was not until 1997, in Wright Medical Technology, Inc. v. Osteonics Corp., 122 F.3d 1440, 1445 (Fed. Cir. 1997), and most references were in 1999 or later. Cf. David J.F. Gross \& Shawn T. Gordon, The Growing Importance of the Claim Vitiation Defense in Patent Cases, COMPUTER \& INTERNET LAW., May 2006, at 19 (discussing the growing use of vitiation doctrine over time). As a result, classing it as a separate test would skew our results, since the term "vitiation" was not in widespread use in our earliest dataset.

46. We encountered virtually no cases applying the prior art doctrine as a defense to the doctrine of equivalents, and have not included it in our dataset.

47. See 35 U.S.C. § 112 para. 6 (2007). On the use of the doctrine of equivalents in this specialized set of cases, see Chiuminatta Concrete Concepts, Inc. v. Cardinal Industries, Inc., 145 F.3d 1303, 1310-11 (Fed. Cir. 1998), which notes that if the asserted equivalent consists of technology existing at the time of patent filing, the plaintiff is limited to proving literal infringement when asserting a "means plus function" claim against the defendant.

48. We did this categorization by hand because of the notorious problems with using the PTO classification system to distinguish among technologies. For a detailed description 
whether each patent was originally owned by a large entity or a small entity. ${ }^{49}$ We also measured several other patent characteristics that ultimately revealed little of interest and which we do not discuss in this Article. ${ }^{50}$

In this Article, we report the descriptive statistics for both the total cases litigated in our study and for each of the three sets of cases individually. We also conducted a number of statistical tests on the relationships between those

of those problems and of the definitions of each category, see John R. Allison \& Mark A. Lemley, Who's Patenting What? An Empirical Exploration of Patent Prosecution, 53 VAND. L. REV. 2099, 2109-12 (2000). The only difference in the technology categories used in the current study from the one developed in Who's Patenting What? is that we now include in the Software category inventions in which the data processing is accomplished by code embedded in chips ("firmware") rather than limiting it to code on a magnetic storage medium.

49. The PTO defines "small entity" as one that meets the requirements of 35 U.S.C. $\S 41(\mathrm{~h})(1)$, which incorporates by reference section 3 of the Small Business Act (codified at 15 U.S.C. § 632 (2007)). Small entities include individuals, nonprofit organizations (such as universities), and corporations with fewer than 500 employees. The remainder of patent owners are large entities. We obtained this data for each patent with the assistance of the PTO. Our data demonstrate only that patents were owned by a particular entity at the time they issued. Many patents are sold or exclusively licensed before they are enforced in court. See Kimberly A. Moore, Populism and Patents, 82 N.Y.U. L. REV. (forthcoming 2007).

50. We measured the number of claims in the patents - a general indicator of litigation propensity and possibly of private (though not necessarily social) patent value. See John R. Allison \& Emerson H. Tiller, The Business Method Patent Myth, 18 Berkeley Tech. L.J. 987, 1052-56 (2003); John R. Allison et al., Valuable Patents, 92 Geo. L.J. 435, 449-53 (2004). We also measured the number of prior art references in these patents, namely, references to prior U.S. patents, prior foreign patents, so-called "nonpatent prior art" (printed publications of many types), and the combined total of all prior art references. Prior research has also shown that numbers of prior art references tend to indicate litigation propensity and private patent value. See Allison \& Tiller, supra, at 1036-39; Allison et al., supra, at 453-55. Not only did we find little or nothing of interest in these metrics in our current study, but we also recognize that it may be premature to examine such patent characteristics for the purpose of determining whether the Festo decisions may have had any effect on the behavior of patent applicants. It is certainly possible that the Festo cases may have affected applicant decisions about the type and number of claims to draft and about the investment to be made in searching for and citing prior art. To ascertain any such effects, however, one would need datasets of patents for which the applications were filed before and after the critical dates. It is too early to gather such data. Moreover, all of the patents in our datasets are litigated patents, in which numbers of claims and prior art references are much higher than in the general population of patents. See, e.g., Allison et al., supra, at 449-55.

We also gathered data on the number of "forward citations"- the number of later patents that cite our patents as being relevant prior art-and adjusted these numbers to account for the fact that we have patents of various ages in our datasets and that a patent obviously tends to receive more such citations as it ages. Research has demonstrated numbers of forward citations to be one of the strongest predictors of both litigation propensity and indicators of private patent value. Id. at 455. Again, we found nothing of interest in this metric - the average adjusted number of forward references was practically identical in each of our three time periods. Moreover, the metric is essentially meaningless in our current study because (1) it is far too early to ascertain whether the Festo decisions had any impact on the factors that tend to cause litigated patents to receive more forward citations, and (2) all of our patents are litigated patents, in which the numbers of forward citations are much higher than in the general population of patents. Id. 
various datasets. In particular, we conducted tests to determine whether the proportion of patent owner wins at various stages and under various circumstances differed from one period to another. In the next Part, we report which of the results are statistically significant and at what confidence level.

\section{RESULTS}

In this Part, we report the results of our analysis, organized first into several key findings and then into several other findings of interest to patent scholars, judges, and lawyers. We present the data in tabular form in Appendix Table 1 (comparing the pre-Festo, mid-Festo, and post-Festo datasets) and Appendix Table 2 (reporting the data from all cases).

\section{A. Patentees Rarely Win}

By far the most dramatic finding of our study is that patentees rarely win doctrine of equivalents cases. Overall, patentees won only $24 \%$ of the doctrine of equivalents cases decided in the last eight years. Compared to the overall patentee win rates on other issues - $54 \%$ on validity alone in cases at various stages of litigation, ${ }^{51}$ and $58 \%$ overall in cases that make it to trial ${ }^{52}$-and the baseline assumption in the economics literature that plaintiffs should win about $50 \%$ of the time, ${ }^{53}$ this is a remarkably small win rate for patentees. This finding is robust across each of the three datasets-patentees won $27.6 \%$ of the cases before Festo, 21.7\% of the cases in the mid-Festo period, and 22.2\% post-Festo. While the changes in Festo arguably had effects in the direction one might predict-patent owners did worse after the absolute bar rule was put into effect, and somewhat better after the rule was moderated to the foreseeable bar-the effects were quite small and not statistically significant. ${ }^{54}$ Doctrine of

51. John R. Allison \& Mark A. Lemley, Empirical Evidence on the Validity of Litigated Patents, 26 AIPLA Q.J. 185, 205-07 (1998) (reporting, inter alia, patentee win rates in all 300 cases in which there was a final written decision on patent validity during 1989-1996, whether decided on pre-trial motion, directed verdict, or after trial).

52. Kimberly A. Moore, Judges, Juries, and Patent Cases-An Empirical Peek Inside the Black Box, 99 MicH. L. REV. 365, 384, 385 n.81 (2000) (reporting percentage of 1209 trial decisions during 1983-1999 in which patentees won judgments of "valid and infringed”).

53. Priest and Klein make the argument for this assumption in George L. Priest \& Benjamin Klein, The Selection of Disputes for Litigation, 13 J. LEGAL STUD. 1 (1984). The rationale is that cases that obviously favor one party or the other should settle, and cases that make it to judgment will be the close ones. As one of the authors has shown elsewhere, however, that hypothesis is not borne out by the data in patent cases. See Mark A. Lemley \& Colleen V. Chien, Are the U.S. Patent Priority Rules Really Necessary?, 54 Hastings L.J. 1299 (2003).

54. We tested the hypotheses that there is no difference in the proportion of cases won by the patentee and the accused infringer in both district court and Federal Circuit cases combined for pre-Festo vs. Federal Circuit Festo, Federal Circuit Festo vs. post-Supreme 
equivalents claims fail in both the district courts and in the Federal Circuit, though it is notable that patentees were much more likely to win on the doctrine of equivalents in district courts before Festo, ${ }^{55}$ and that as a result district courts overall were substantially more likely to rule for patentees than the Federal Circuit was (30.6\% versus $16.8 \%$ ).

These results remain robust regardless what test the court used for equivalence and what defenses were asserted, again with some variation: in district courts and the Federal Circuit combined, patentees won $17.9 \%$ of the cases involving the all-elements rule, $33.5 \%$ of the cases involving the function-way-result test, $29.5 \%$ of the cases involving the insubstantial differences test, $26.9 \%$ of the cases involving prosecution history estoppel, and $25 \%$ of the cases involving dedication to the public domain.

While there is variation in each of these numbers, what is notable is that none of them is even close to $50 \% .{ }^{56}$ Even in the cases litigated to judgment, patentees overwhelmingly lose doctrine of equivalents cases. The problem is even worse for patentees than these numbers suggest. More than two-thirds of the "victories" by patent owners in the dataset-68 out of 99 total winssimply involved defeating an accused infringer's motion for summary judgment. While a significant victory, it is hardly the same as actually winning the case on equivalents grounds. Indeed, only 29 cases out of the 413 we studied-less than $10 \%$ of the total-involved a patentee actually winning the case on equivalents grounds. The doctrine of equivalents is for all intents and purposes dead, and has been for years, even as lawyers and judges were seeing it as too expansive and struggling to cabin it. In Part IV, we investigate what killed it.

Court Festo, and pre-Festo vs. post-Supreme Court Festo. None of the hypotheses could be rejected (p-values of $0.30,0.96$, and 0.19 , respectively).

55. Patentees won $43.9 \%$ of the doctrine of equivalents cases in the district court before Festo, the only number that approaches the Priest-Klein 50\% baseline. The difference between this number and the post-Festo number was statistically significant with a high degree of confidence. The hypothesis that there is no difference in the proportion of cases the patentee won in district court pre-Festo vs. post-Supreme Court Festo was rejected $(\mathrm{p}=0.000)$.

56. All of these results were statistically significant. We can reject each of the following hypotheses with great confidence $(p=0.000)$ : $(1)$ there is no difference in the proportions of cases won by the patentee and by accused infringer when the court uses the all elements test, the "FWR" test, the "insubstantial differences" test, or more than one of the tests; (2) there is no difference in the proportion of cases won by the patentee and by accused infringer in both district court and Federal Circuit cases combined; (3) there is no difference in the proportion of cases won by the patentee and the accused infringer in district court; and (4) there is no difference in the proportion of cases won by the patentee and the accused infringer in Federal Circuit cases. 


\section{B. Do the Legal Rules Matter?}

The second striking finding is that Festo seemed to have essentially no effect on the types of cases it most directly concerned. We have already noted that the differences in patentee win rates over the three periods are extremely modest - a total variation of less than $6 \%$, and one that was not statistically significant. But even if that modest variation is not just statistical noise, there is reason to doubt whether it is attributable to Festo. The actual holding of both the Federal Circuit and Supreme Court governed not the general standard for the doctrine of equivalents, but the specific question of the rules governing prosecution history estoppel, and (even more precisely) the rules governing the subset of prosecution history estoppel cases based on the patentee's amendment of the claims. So if the significant shifts in rules in Festo from pro-patentee to anti-patentee to a middle approach were to have any effect, it should presumably appear in prosecution history estoppel cases, and specifically in the estoppel cases based on amendment rather than argument.

In fact, however, the data suggest the opposite: if anything, patentees did better under the rules that were worse for them. As Appendix Table 1 demonstrates, patentees won only $13.6 \%$ of the prosecution history estoppel cases in the pre-Festo period, when the rules were most favorable to them. Between 2000 and 2002, when the rules were most anti-patentee, patentees actually did significantly better in prosecution history estoppel cases than they did under the more favorable rules, winning $30.8 \%$ of the cases. ${ }^{57}$ They did slightly better still after 2002, winning 33.3\% of the estoppel cases, but the difference is not statistically significant. ${ }^{58}$ A similar pattern appears with the subset of estoppel cases involving amendment-the very issue affected by Festo. Patentees won only $12.5 \%$ of the amendment estoppel cases in the nominally pro-patentee pre-Festo period. In the absolute bar period that number went up to $21.2 \%$, though the increase is not statistically significant. ${ }^{59}$ It increased even more substantially after the Supreme Court decision, to $42.1 \%$, but again the increase is not statistically significant. ${ }^{60}$

57. This difference was statistically significant, but barely. The hypothesis that there is no difference in the proportion of prosecution history estoppel (PHE) cases won by the patentee and the accused infringer in both district court and Federal Circuit cases combined, pre-Festo vs. Federal Circuit Festo, can be rejected with 95\% confidence, but not much more than that $(\mathrm{p}=0.047)$.

58. The hypothesis that there is no difference in the proportion of PHE cases won by the patentee and the accused infringer in both district court and Federal Circuit cases combined, Federal Circuit Festo vs. post-Supreme Court Festo, could not be rejected $(\mathrm{p}=0.77)$.

59. The hypothesis that when PHE is an issue there is no difference in the proportion of cases won by the patentee when the estoppel is based on a claim amendment, pre-Festo vs. Federal Circuit Festo, could not be rejected $(\mathrm{p}=0.35)$.

60. The hypothesis that when PHE is an issue there is no difference in the proportion of cases won by the patentee when the estoppel is based on a claim amendment, Federal Circuit vs. post-Supreme Court Festo, could not be rejected with much confidence 
These results are hard to explain. It is surprising that when the law gets worse for patentees, they do better in cases that directly present those legal questions. One possible explanation might be that after the Federal Circuit's decision in Festo, many more defendants responded by raising weaker prosecution history estoppel claims, claims they would not have made under a tougher legal standard, and courts were more likely to reject those weaker claims. We don't think that this is the real explanation, however, for two reasons. First, it is not the case that there were appreciably more prosecution history estoppel decisions after the Federal Circuit's decision or fewer after the Supreme Court reversal. There is a modest increase in the percentage of DOE cases decided on prosecution history estoppel grounds after the Federal Circuit's decision, and decrease after the Supreme Court opinion, from 30.3\% of cases to $45.2 \%$ of cases to $39.2 \%$ of cases. But the effect is only modest, and neither the second change nor the overall change from the first to third period is statistically significant. ${ }^{61}$ Further, the relationship disappears when we look at the subset of estoppel cases based on amendment (rather than argument), which should be the ones causing this purported effect. The share of estoppel cases based on amendment actually drops from $72.7 \%$ of estoppel cases pre-Festo to 63.5\% after the Federal Circuit opinion and to $63.3 \%$ after the Supreme Court opinion. ${ }^{62}$ Second, the seemingly inverse relationship also shows up in the subset of estoppel cases decided in the Federal Circuit. The Federal Circuit found for patentees in only $8.8 \%$ of its estoppel cases during the pre-Festo period. After that court changed the law to favor accused infringers, that win rate actually doubled, to $17.2 \%$. It jumped further, to $47.4 \%$, after the Supreme Court's opinion. ${ }^{63}$ Because of the short time periods involved, these cases were already filed, and likely already decided by the district courts, before the intervening change in the law. Any estoppel arguments the Federal Circuit heard between 2000 and 2002 were almost certainly originally made under the pre-Festo standard. So the fact that those decisions show the same pattern suggests that case selection can't be responsible for the result. ${ }^{64}$

( $p=0.061$ ). The differences between these percentages seem large, but by the time we have narrowed the issue to PHE cases based on amendment, the number of observations drops to a level such that differences of even larger magnitudes would be necessary for a finding of statistical significance. The lack of statistical significance caused by the substantially reduced number of cases should not obscure the fact that these differences are in a direction diametrically opposed to what one would expect from the changes in legal rules.

61. We tested the following hypotheses: that there is no difference in the proportion of DOE cases in which PHE is an issue for (1) pre-Festo vs. Federal Circuit Festo; (2) Federal Circuit Festo vs. post-Supreme Court Festo; and (3) pre-Festo vs. post-Supreme Court Festo. Only the first hypothesis could be rejected (p-values of $0.014,0.32$, and 0.11 , respectively).

62. Because there are different numbers of cases in each of our three datasets, percentages rather than actual numbers are more useful for comparison.

63. There were too few of these decisions to run meaningful statistical tests on them.

64. While it is theoretically possible that parties who would otherwise have settled their estoppel claims on appeal pursued the appeal instead, it seems unlikely that very many 
We think the most plausible explanation is a rather dramatic one-the legal standard simply doesn't matter very much in this set of cases. We explore the likely reason for this in Part IV.

\section{Other Findings}

While the two findings just discussed are the most dramatic, there are a number of other interesting findings from these data.

\section{Learning effects in the district courts}

Our dataset conflates both district court and Federal Circuit decisions. Disaggregating them provides some interesting insights. First, the Federal Circuit overall appears significantly more hostile to the doctrine of equivalents than do the district courts. Overall, patentees won $30.6 \%$ of the cases in the district courts, but barely more than half that-16.8\%—in the Federal Circuit. Second, the Federal Circuit's opinions reflect modest effects that are at least partially correlated to the direction of legal doctrines. The Federal Circuit found for patentees in $17.1 \%$ of the pre-Festo cases. That number dropped to $10.8 \%$ after the Federal Circuit decided Festo, and rose to $25.6 \%$ after the Supreme Court reversed. ${ }^{65}$ By contrast, the story in the district courts is one of decline for patent owners. District court judges found for patentees quite frequently in the $1999-2000$ period: $43.9 \%$ of the time. That number falls to $36.0 \%$ of cases during the mid-Festo period and even further, to $20.9 \%$, after the Supreme Court decision. ${ }^{66}$

One possible explanation for this result is a time-lagged learning effect. Under this theory, district courts follow the law, but it takes some time for trends in Federal Circuit decisions to emerge and be applied by the district courts. ${ }^{67}$ The explanation would go something like this: district courts at the

cases that made it all the way through the expensive district court litigation process settled in order to save the small additional amount of money it would take to resolve the appeal.

65. Only the increase from the middle (Federal Circuit Festo) period to the period after the Supreme Court decision is statistically significant, and it is barely so. We tested the following hypotheses: that there is no difference in the proportion of cases won by the patentee and the accused infringer in Federal Circuit cases, (1) pre-Festo vs. Federal Circuit Festo; (2) Federal Circuit Festo vs. post-Supreme Court Festo; and (3) pre-Festo vs. postSupreme Court Festo. Only the second hypothesis could be rejected (p-values of 0.30, 0.041, and 0.25 , respectively).

66. The overall drop is statistically significant, and the second period drop is marginally significant, but the first is not. We tested the following hypotheses: that there is no difference in the proportion of cases won by the patentee and the accused infringer in district court cases, (1) pre-Festo vs. Federal Circuit Festo; (2) Federal Circuit Festo vs. post-Supreme Court Festo; and (3) pre-Festo vs. post-Supreme Court Festo. Both the second and third hypotheses could be rejected, the last with great confidence (p-values were 0.46 , 0.035 , and 0.002 , respectively).

67. The most obvious explanation-the well-known tendency of juries to favor 
beginning of our study were applying Federal Circuit rules presumably set in an even earlier period. The Federal Circuit in the late 1990s cut back on the doctrine of equivalents, and cut back even further in Festo. The effects of that general move were seen in district court cases after 2000, dropping throughout the second and third datasets. On this explanation, one ought to expect a rebound effect in the future, with district courts modestly increasing the strength of the doctrine of equivalents.

It is not clear the data bear this hypothesis out, however. We obtained a fourth dataset of cases decided on the doctrine of equivalents between September 1, 1993 and March 1, 1995-an eighteen-month period before the Federal Circuit decision in Markman. The results from that dataset are reported in Table 3. In that time period, patentees won $47.7 \%$ of district court cases, but only $23.3 \%$ of Federal Circuit cases. While the higher number of wins in the district court during that period is consistent with the lagged decline story, the fact that the Federal Circuit was unlikely to rule for patentees even in the early 1990s suggests that any learning effect had a long lag time indeed.

An alternative explanation is the role of procedural posture in district court decisions, specifically decisions on summary judgment motions filed by accused infringers. The data show that by far the largest number of cases deciding the doctrine of equivalents - approximately two-thirds of all the cases in the dataset-arise on summary judgment motions filed by accused infringers. ${ }^{68}$ It is these cases that drive much of the move towards rulings for accused infringers—a patentee win rate on summary judgment motions filed by accused infringers that dropped from $29.8 \%$ in the pre-Festo period to $17.7 \%$ in the middle period and then remained essentially the same in the last period, $18.9 \%$. As district courts increasingly grant summary judgment to accused infringers, the overall patentee win rate declines in district courts. We speculate in Part IV on what may be driving the move towards summary judgment.

patentees more than judges, see Allison \& Lemley, supra note 51, at 212 tbl.3; Moore, supra note 52 , at 368-is unlikely to be the correct one because of the small number of jury verdicts in our study (21 out of 413 total cases, and 8 patentee wins out of 99).

68. We reiterate that the universe of reported decisions is not the same as the universe of all decided cases. In particular, it tends to significantly underreport jury verdicts. To help correct for this bias, at least at the appellate level, we enlisted the aid of Paul Janicke at the University of Houston, who runs the ipstats.org database. He evaluated Rule 36 affirmances (those issued without written opinion) during the period of our study (other than six months in 1999 for which he did not have data), and found that the patentee won 1 of $6(16.7 \%)$ Rule 36 affirmances on doctrine of equivalents in the pre-Festo period, 0 of $13(0 \%)$ midFesto, and 2 of 11 (18\%) post-Festo. These percentages are somewhat smaller than the ones we find in written decisions, but because the actual number of cases in each period is small, they would not significantly affect our overall results. 


\section{Who uses the doctrine of equivalents?}

\section{a. Industry differences}

It is clearer and clearer that different industries experience the patent system in very different terms. They innovate differently, they get patents differently, and they use those patents differently. ${ }^{69}$ These differences have manifested themselves most recently in debates over legislative patent reform, which have pitted the biotechnology and pharmaceutical industries against the information technology industries on virtually every issue. ${ }^{70}$ It is reasonable to assume, therefore, that the differences we see in patent prosecution and litigation more generally would also show up in doctrine of equivalents cases.

We hand-categorized each of the 413 patents at issue in these cases into one or more of fourteen technology areas. ${ }^{71}$ We do find significant selection effects: doctrine of equivalents cases are more likely to show up in some technology areas than others. Most notable is the large number of mechanical devices at issue in these cases- $61.7 \%$ of all cases in our dataset, compared to a much smaller $32.9 \%$ among prosecuted patents more generally. ${ }^{72}$ The other industries in which the doctrine of equivalents is heavily used are software (22.0\% of all equivalents cases, compared to $7.6 \%$ more generally), ${ }^{73}$ and

69. Dan L. Burk \& Mark A. Lemley, Tailoring Patent Law for Different InDUSTRIES (forthcoming 2007); Dan L. Burk \& Mark A. Lemley, Policy Levers in Patent Law, 89 VA. L. REV. 1575 (2003). For empirical proof of this, see John R. Allison \& Mark A. Lemley, The Growing Complexity of the United States Patent System, 82 B.U. L. REV. 77 (2002).

70. See, e.g., Jay Dratler, Jr., Invention Is a Process, or Why the Electronics and Pharmaceutical Industries Are at Loggerheads Over Patents, 21 BERKELEY TECH. L.J. (forthcoming 2007).

71. For the definition of those areas, see Allison \& Lemley, supra note 48, at 2109-12. As previously noted, there is only one difference in our current typology from that used earlier - the definition of software has been expanded to include firmware.

72. Id. at 2148 tbl.1. The two sets are not entirely comparable, because the prosecution study includes only patents issued between 1996 and 1998, while this study includes cases litigated between 1998 and 2005. Because of the significant lag time between patent issuance and final judgment-an average of 8.6 years, see Allison \& Lemley, supra note 51, at 236 tbl.12-many of the patents in this study issued somewhat before 1996. Since mechanical patents as a proportion of all issued patents have declined steadily over the years, see Allison \& Lemley, supra note 69, at 93 tbl.1 (from 52.0\% during 1976-1978 to $32.9 \%$ during 1996-1998), the divergence in shares of mechanical patents may not be as great as the numbers in the text make it appear. Further, a significantly larger percentage of mechanical patents relative to their representation in the population of issued patents are litigated, resulting in disproportionate representation in our doctrine of equivalents cases. See Allison et al., supra note 50, at 472-74. Nonetheless, because only $52 \%$ of patents were mechanical even in the 1970s, and presumably fewer were mechanical by the early 1990s, their overrepresentation in doctrine of equivalents litigation is clearly real.

73. Allison \& Lemley, supra note 48, at 2148 tbl.1. The overrepresentation of software patents is even more striking since software patents are fairly new, and before 1996 they likely represented even fewer than $7.6 \%$ of all patents. The $7.6 \%$ and $22.0 \%$ figures for software patents are not comparable for another previously noted reason: the definition of 
electronics (19.6\% of all equivalents cases, compared to $7.7 \%$ of patents more generally). ${ }^{74}$ Pharmaceuticals ( $6.5 \%$ of equivalents cases, compared to $7.8 \%$ of all patents) and biotechnology (2.7\% of equivalents cases, compared to $3.7 \%$ of all patents), ${ }^{75}$ by contrast, are modestly underrepresented in the equivalents case law. These results make some intuitive sense. The doctrine of equivalents was designed with mechanical inventions in mind, and the primary test for the doctrine-the "tripartite" or "function-way-result" test-works best with mechanical inventions. ${ }^{76}$ And, as one of the authors has argued elsewhere, the doctrine will play a more important role in the information technology industries because of both the rapid pace of product change and the uncertain scope of product claims in those industries. ${ }^{77}$ In pharmaceuticals and biotechnology, by contrast, claim language is a much clearer way of expressing patent scope, and the doctrine is correspondingly less important.

Somewhat surprisingly, we find no similar industry-specific differences in outcomes. Considering only those technologies with ten or more patentee wins $^{78}$-medical devices, computer-related inventions, software, chemistry, electronics, mechanics, and optics - we find no technology area with a patentee win rate that is less than $22.2 \%$ or more than $29.0 \%$, a remarkably narrow range that closely brackets the overall patentee win rates. While technology area affects whether people raise the doctrine of equivalents, therefore, it doesn't seem to affect outcomes.

\section{b. Large versus small entities}

"Small entities"-individuals, non-profits, and small companies-obtain around a quarter of all patents. Our data indicates, however, that those patents are much more likely to be involved in litigation. Almost half of the doctrine of equivalents cases in our dataset (47.9\%) involve patents granted to small

software in the current study adds patents covering inventions in which the data processing is carried out by code in chips. This expanded definition is unlikely to account for the huge discrepancy between $7.6 \%$ and $22.0 \%$, however. As with mechanical patents, a larger percentage of software patents are litigated relative to their representation in the population of issued patents, resulting in a larger percentage of software patents being found in our set of doctrine of equivalents decisions. See Allison et al., supra note 50, at 472-74. The greater propensity to litigate software patents is certainly a recent phenomenon, something that was not true of mechanical patents.

74. Id.

75. Id.

76. See, e.g., Warner-Jenkinson Co. v. Hilton Davis Chem. Co., 520 U.S. 17, 39-40 (1997) ("There seems to be substantial agreement that, while the triple identity test may be suitable for analyzing mechanical devices, it often provides a poor framework for analyzing other products or processes.”).

77. See Julie E. Cohen \& Mark A. Lemley, Patent Scope and Innovation in the Software Industry, 89 CAL. L. REV. 1, 45-47 (2001).

78. The small numbers of the other technologies make it impossible to draw any meaningful conclusions from those technologies. 
entities. This is largely consistent with our earlier findings about litigation more generally. ${ }^{79}$ These small-entity patents are modestly less successful than largeentity patents: they win only $20.2 \%$ of the time. Further, their win rate has been declining over time-from $25.7 \%$ in the first dataset to $20.0 \%$ in the second and $14.7 \%$ in the final dataset. ${ }^{80}$ The decline in the final dataset, even as patentees overall did modestly better than in the Federal Circuit Festo period, is particularly interesting.

One possible conclusion to draw from these data is that courts are reacting negatively to so-called "patent trolls": entities that don't manufacture products of their own but sue others who do. An alternative, more plaintiff-friendly interpretation of the same result would be that the system is systematically biased against small entities. We caution against both interpretations. The fact that an entity is "small" doesn't mean that it is a troll or a non-manufacturing entity. They may be universities ${ }^{81}$ or small companies that do manufacture products. Similarly, the fact that a plaintiff is small and loses its case does not demonstrate that the system is biased against small entities, because we don't know how big the defendant in the case was. Most importantly, our data measure only who owned the patent at the time it issued. A surprisingly large number of litigated patents are sold or exclusively licensed before suit, so that the entity bringing the suit is not the entity that originally obtained the patent. ${ }^{82}$ So while some of this effect may be troll-related, there is no way to know how much.

\section{What arguments prevail?}

Those who deal with patent litigation on a regular basis want answers to a more practical question - what arguments are most likely to win? Our descriptive statistics provide useful insights into this question.

We begin with the three different tests the Federal Circuit uses for determining equivalence-the tripartite function-way-result test, the insubstantial differences test, and the all elements/vitiation rule. We read each case individually and made a judgment as to which of these tests were actually applied (as opposed to merely invoked by rote). The first thing we discovered was that courts commonly applied more than one framework. Of the 413 cases

79. See Allison et al., supra note 50, at 466.

80. This decline is not statistically significant, however. We could not reject the hypotheses that there is no difference in the proportion of cases won by the patentee when the patentee is a "small entity" for (1) pre-Festo vs. Federal Circuit Festo; (2) Federal Circuit Festo vs. post-Supreme Court Festo; or (3) pre-Festo vs. post-Supreme Court Festo (p-values of $0.44,0.43$, and 0.11 , respectively).

81. On the question of whether universities should be considered patent trolls, see Mark A. Lemley, Are Universities Patent Trolls? (2006) (unpublished manuscript, on file with authors).

82. Moore, supra note 49. 
in our dataset, 126 used more than one test. When the court applied more than one test, patentees prevailed almost $31 \%$ of the time. Of the three tests individually, the most successful for plaintiffs was the function-way-result approach. Over one-third of decisions applying this test (33.5\%) ruled for patentees. That is still not a great win rate, but it is better than how patentees fared under the insubstantial differences approach (they won 29.5\% of such cases). Patentees fared the worst when courts applied the all elements rule, winning only $17.9 \%$ of such cases. This is probably because the all elements rule is intended as a limiting doctrine, and a court is likely to invoke it (or the related "vitiating an element" approach) only where the patentee is arguing for an interpretation that would effectively eliminate an element of the patent claim.

Among limitations on the doctrine of equivalents, prosecution history estoppel is unsurprisingly the most important, raised in $37.8 \%$ of all cases. Of the 156 cases with estoppel claims, 103 involve assertion of amendment-based estoppel and 65 involve argument-based estoppel. ${ }^{83}$ Patentees won only $26.9 \%$ of the 156 cases in which estoppel was asserted by the accused infringer. The numbers were effectively the same for both amendment-based and argumentbased estoppel (patentees won $26.2 \%$ and $27.7 \%$ respectively). The doctrine of dedication to the public domain, established by the Federal Circuit in 2002, played a much more minor role. It was raised only twelve times, and the patentee won $25 \%$ of those cases.

Finally, we identified a surprisingly large number of cases-75, or $18.2 \%$ of all cases - that involved the application of the doctrine of equivalents to a so-called "means-plus-function" claim element. ${ }^{84}$ Means-plus-function claim elements are generally considered narrower than ordinary patent claims, though there was a time when that was not true. ${ }^{85}$ Some have speculated, however, that they may be more useful after Festo and its progeny because they are unlikely to be amended during prosecution in the PTO and therefore unlikely to trigger prosecution history estoppel. ${ }^{86}$ Our results suggest that this speculation is

83. The discrepancy between 156 and the sum of 103 plus 65 is accounted for by a small number of cases in which both types of estoppel were asserted by accused infringers. Somewhat strangely, almost all of the cases in which both bases for estoppel were asserted occurred in the earliest, pre-Festo period (nine out of twelve).

84. A means-plus-function claim element is one drafted in the form "means for doing $\mathrm{x}$," without disclosing what means perform the function. Under 35 U.S.C. § 112, claims of this sort are interpreted to cover the specific means identified in the patent's written description and equivalents thereof.

85. Cf. Robert P. Merges \& John F. Duffy, Patent Law and Policy 32 (3d ed. 2002) (suggesting that such claims are quite broad, a holdover from an earlier view-and perhaps from an earlier edition of the book).

86. See, e.g., William M. Atkinson et al., Losing Ground: The Extension of Festo in Honeywell v. Hamilton Sundstrand, InTELL. Prop. L. CommitTeE NewSL., Spring 2005, at 10; Scott G. Ulbrich, Festo, Notice and the Application of Prosecution History Estoppel to Means-Plus-Function Claim Limitations, 28 WM. MitCHELL L. REV. 1165 (2002). 
wrong. Patentees won only 5.3\% of the doctrine of equivalents cases involving means-plus-function claims, the lowest win rate on any issue in our study. This is likely due to the specific legal rules surrounding such claims, which provide a smaller role for the doctrine of equivalents. ${ }^{87}$ Regardless of the reason, however, it seems clear that writing means-plus-function claims is not likely to avoid the limits of Festo.

\section{Does case publication matter?}

A final finding has nothing to do with patent law. In the data we collected, we distinguished between "published" and "unpublished" cases. One might reasonably suppose that the subset of cases selected for publication differ in some significant way from the ones designated unpublished, whether because courts choose to publish the harder decisions, the more important ones, or the ones involving fact patterns unlike many previous decisions. If that is true, any study that relied only on published opinions would introduce a bias. In fact, however, the numbers are almost indistinguishable-patentees won $22.0 \%$ of published decisions, compared to $24.0 \%$ of all decisions. And while appellate opinions are more likely to be published than district court opinions, that fact doesn't affect the results - the published district court and appellate court numbers map closely to the overall numbers (in the district court, patentees won $26.9 \%$ of the published cases and $30.6 \%$ of the overall cases; in the Federal Circuit, patentees won $17.6 \%$ of the published cases and $16.8 \%$ of the overall cases). The fact that published opinions appear to be a representative subset of all opinions is a good sign, both for the (controversial and soon to be ended) ${ }^{88}$ practice of non-publication and for studies that rely on published opinions. $^{89}$

\section{WHAT’S GOING ON HERE?}

The previous part suggests that the enormous attention paid to changes in the rules governing the doctrine of equivalents in general, and prosecution history estoppel in particular, was wasted. The doctrine of equivalents was

87. Chiuminatta Concrete Concepts, Inc. v. Cardinal Indus., Inc., 145 F.3d 1303, 1310 (Fed. Cir. 1998) (stating that if the asserted equivalent consists of preexisting technology, the plaintiff must prove literal infringement or nothing when asserting a "means plus function" claim against the defendant).

88. See FED. R. App. P. 32.1 (amended effective 2007) (requiring courts to permit citation of all written opinions, not just those designated "for publication").

89. It does not mean, however, that they are also representative of decisions with no opinion at all. Affirmances without opinion under Fed. Cir. R. 36 and jury verdicts have characteristics that are likely to make them fundamentally different than decisions with written opinions. Nonetheless, as mentioned in supra note 68, Paul Janicke's evaluation of Rule 36 doctrine of equivalents cases suggests that the differences between those cases and the written ones were not significant. 
largely dead by 1998, at the height of the debate over the expansiveness of the rule. Further, changing the prosecution history rules had essentially no effect, either on the patentee win rate on the doctrine of equivalents more generally or even in the subset of prosecution history estoppel cases. What explains this remarkable result? Does the law on the books not matter at all, as an extreme version of legal realism might suggest? ${ }^{90}$ There is likely something to this explanation. Doctrine of equivalents cases are quite fact-specific, and one explanation for the indifference of results to the legal standards is that judges are simply making a gut determination of whether the accused device is sufficiently similar to the patented invention. But we think there is more going on here. A strict legal realist view might explain invariance to changes in legal rules, but not why so few patentees win at all on the doctrine of equivalents.

We suspect that the real driving force behind the dramatic decline of the doctrine of equivalents is not a doctrine of equivalents case at all, but the Supreme Court's Markman claim construction decision. ${ }^{91}$ The key to understanding this seemingly bizarre suggestion is that doctrine of equivalents issues do not arise in isolation. Rather, a patentee is almost always arguing the doctrine of equivalents as an alternative to a theory of literal infringement. Before the Supreme Court's 1996 Markman decision, both the literal infringement and the doctrine of equivalents issues presented factual questions frequently left for the trier of fact. But once Markman held that claim construction was a question of law, judges started construing the claims of the patent in pre-trial “Markman hearings.” Having construed the claims, district courts increasingly resolved literal infringement claims on summary judgment, since there was rarely a factual dispute over what the defendant's product actually did. ${ }^{92}$ But having gone to all the trouble of construing the patent claims and ruling on literal infringement on summary judgment, district courts then found that they couldn't dispose of the case pretrial unless they could also resolve the doctrine of equivalents issue. This is particularly true if the district court finds no literal infringement; the patentee will use the doctrine of equivalents as a second bite at the apple. As a result, judges increasingly sought to resolve the doctrine of equivalents as well as literal infringement on summary judgment. A judge who has just rejected a literal infringement claim, and who knows that the only way to dispose of the case (or to get the equivalent of an interlocutory appeal of her claim construction ruling) is to similarly reject the doctrine of equivalents claim, will be doubly inclined to hold for the accused infringer. And indeed a significant majority of all cases in

90. For a general explanation of legal realism, see, for example, Thomas C. Grey, Modern American Legal Thought, 106 YALE L.J. 493, 500-02 (1996) (reviewing NEIL DUXBURY, PATTERNS OF AMERICAN JURISPRUDENCE (1995)).

91. Markman v. Westview Instruments, Inc., 517 U.S. 370 (1996).

92. See, e.g., William F. Lee \& Anita K. Krug, Still Adjusting to Markman: A Prescription for the Timing of Claim Construction Hearings, 13 HARV. J.L. \& TECH. 55, 59 (1999) (predicting that Markman would lead to greater use of summary judgment). 
our dataset resolve the doctrine of equivalents on summary judgment, the vast majority of them against the patent owner.

To test this hypothesis, we went back and collected a fourth set of doctrine of equivalents cases decided in 1993 through 1995, before the Federal Circuit or Supreme Court decisions in Markman..$^{93}$ A time period equivalent to that in our other three datasets produced ninety-five decisions, a smaller number than in more recent years. Analyzing those cases supports our hypothesis. Before Markman, patentees won $40.0 \%$ of the doctrine of equivalents cases, compared with only $24 \%$ in our three primary datasets. ${ }^{94}$ As noted above, most of this effect came from district courts, which ruled for patentees $47.7 \%$ of the time in the pre-Markman cases. The differences also show up across a range of issues. Patentees won $40.7 \%$ of the prosecution history estoppel cases before Markman, compared with $26.9 \%$ in the three primary datasets. They won $23.5 \%$ of the all-elements cases and $41.7 \%$ of the function-way-result cases pre-Markman, compared with $17.9 \%$ and $33.5 \%$ respectively in the primary datasets. ${ }^{95}$

These data also allow us to reject a competing hypothesis - the idea that doctrine of equivalents arguments are "also-rans," add-on arguments that are often pressed half-heartedly and so unsurprisingly fail most of the time. While this theory has the ring of plausibility, the fact that courts used to look more favorably on doctrine of equivalents arguments than they do today leads us to doubt that explanation.

\section{CONCLUSION}

The broader lesson here is the importance of understanding not just the law on the books, but the law on the ground. The doctrine of equivalents practically succumbed not because the courts restricted the doctrine itself, but because changes in the procedural circumstances in which equivalents cases are heard caused courts to lump them together with literal infringement determinations and therefore to make it more likely that they will be resolved in the same way

93. We chose to study doctrine of equivalents cases during the eighteen months prior to the Federal Circuit decision in Markman because it was in accord with the subsequent Supreme Court decision and, thus, the rule change occurred in the Federal Circuit case.

94. This difference is statistically significant with a high degree of confidence. We tested the hypothesis that there is no difference in the proportion of cases won (overall DOE win) by patentees between the pre-Markman and post-Festo datasets. That hypothesis was strongly rejected $(\mathrm{p}=0.003)$.

95. There were too few insubstantial differences cases pre-Markman for valid comparison.

The fact that the much larger patentee win rate before Markman was primarily the result of a very large win rate in district courts, the win rate in the Federal Circuit still having been quite low during that earlier period, leaves a remaining question: was there ever a time when patentees won a substantial portion of doctrine of equivalents cases in the Federal Circuit? This is an empirical question for further research. 
as those decisions. And since the doctrine of equivalents exists only as a backstop for patentees who lose on literal infringement, lumping them together makes it much more likely that a fact-finder that rejects one claim will reject them both. We have found in a different study that fact-finders tend to make all-up or all-down decisions even for unrelated issues like the validity of entirely different patents. ${ }^{96}$ In this case, where the two decisions are related, the tendency should be even stronger. The doctrine of equivalents may have been a victim of this aggregation effect. The fact that it has not been noticed suggests that courts, scholars, and even lawyers need to pay more attention than they do to the unintended practical consequences of changes in legal rules. Changes in procedure can affect substantive decisions.

96. Allison \& Lemley, supra note 51, at 245 tbl.18 (finding that patents litigated together were held either all valid or all invalid $86.7 \%$ of the time). 


\section{APPENDIX}

Table 1. Comparisons Among Pre-, Mid-, and Post-Festo Datasets

\begin{tabular}{|c|c|c|c|c|c|c|}
\hline & \multicolumn{2}{|c|}{ Pre-Festo } & \multicolumn{2}{|c|}{$\begin{array}{c}\text { Federal Circuit } \\
\text { Festo }\end{array}$} & \multicolumn{2}{|c|}{$\begin{array}{c}\text { Post-Supreme } \\
\text { Court Festo }\end{array}$} \\
\hline & Number & Percent & Number & Percent & Number & Percent \\
\hline & \multicolumn{6}{|c|}{ All Cases } \\
\hline Total Cases & 145 & & 115 & & 153 & \\
\hline District Court & 57 & & 50 & & 110 & \\
\hline Federal Circuit & 88 & & 65 & & 53 & \\
\hline Patentee Wins & 40 & $27.6 \%$ & 25 & $21.7 \%$ & 34 & $22.2 \%$ \\
\hline Patentee Wins in District Court & 25 & $43.9 \%$ & 18 & $36.0 \%$ & 23 & $20.9 \%$ \\
\hline Patentee Wins in Federal Cicuit & 15 & $17.1 \%$ & 7 & $10.8 \%$ & 11 & $25.6 \%$ \\
\hline PHE Is an Issue & 44 & $30.3 \%$ & 52 & $45.2 \%$ & 60 & $39.2 \%$ \\
\hline Patentee Wins & 6 & $13.6 \%$ & 16 & $30.8 \%$ & 20 & $33.3 \%$ \\
\hline PHE Is an Issue in District Court & 10 & $17.5 \%$ & 23 & $46.0 \%$ & 41 & $37.3 \%$ \\
\hline Patentee Wins & 3 & $30.0 \%$ & 11 & $47.8 \%$ & 11 & $26.8 \%$ \\
\hline PHE Is an Issue in Federal Circuit & 34 & $38.6 \%$ & 29 & $44.6 \%$ & 19 & $44.2 \%$ \\
\hline Patentee Wins & 3 & $8.8 \%$ & 5 & $17.2 \%$ & 9 & $47.4 \%$ \\
\hline PHE Cases Based on Amendment & 32 & $72.7 \%$ & 33 & $63.5 \%$ & 38 & $63.3 \%$ \\
\hline Patentee Wins & 4 & $12.5 \%$ & 7 & $21.2 \%$ & 16 & $42.1 \%$ \\
\hline PHE Cases Based on Argument & 21 & $47.7 \%$ & 20 & $38.5 \%$ & 24 & $40.0 \%$ \\
\hline \multirow[t]{2}{*}{ Patentee Wins } & 2 & $9.5 \%$ & 10 & $50.0 \%$ & 6 & $25.0 \%$ \\
\hline & \multicolumn{6}{|c|}{ Cases Won by Patentee by Stage of Litigation } \\
\hline Preliminary Injunction & 5 & $50.0 \%$ & 1 & $25.0 \%$ & 2 & $100.0 \%$ \\
\hline SJ Filed by Patentee & 0 & $0.0 \%$ & 3 & $21.4 \%$ & 1 & $10.0 \%$ \\
\hline SJ Filed by Accused Infringer & 31 & $29.8 \%$ & 14 & $17.7 \%$ & 23 & $18.9 \%$ \\
\hline Jury Trial & 1 & $11.1 \%$ & 4 & $80.0 \%$ & 3 & $42.9 \%$ \\
\hline Bench Trial & 1 & $9.1 \%$ & 2 & $22.2 \%$ & 4 & $44.4 \%$ \\
\hline JMOL Filed by Patentee & 2 & $66.7 \%$ & 1 & $100.0 \%$ & 0 & $0.0 \%$ \\
\hline \multirow[t]{2}{*}{ JMOL Filed by Accused Infringer } & 1 & $25.0 \%$ & 0 & $0.0 \%$ & 1 & $33.33 \%$ \\
\hline & \multicolumn{6}{|c|}{ Cases Won by Patentee at Federal Circuit by Decision Type } \\
\hline Affirmance & 4 & $6.3 \%$ & 2 & $4.8 \%$ & 2 & $7.41 \%$ \\
\hline Reversal & 0 & $0.0 \%$ & 2 & $25.0 \%$ & 2 & $28.57 \%$ \\
\hline Remand & 11 & $84.6 \%$ & 3 & $27.3 \%$ & 7 & $77.78 \%$ \\
\hline \multirow[t]{2}{*}{ Reversal and Remand } & 11 & $45.8 \%$ & 5 & $26.3 \%$ & 9 & $56.25 \%$ \\
\hline & \multicolumn{6}{|c|}{ Cases at Federal Circuit by DOE Test Used } \\
\hline All Elements Rule & 39 & $26.9 \%$ & 46 & $40.0 \%$ & 66 & $43.14 \%$ \\
\hline Patentee Wins & 8 & $20.5 \%$ & 10 & $21.7 \%$ & 9 & $13.64 \%$ \\
\hline FWR Test & 65 & $44.8 \%$ & 42 & $36.5 \%$ & 57 & $37.25 \%$ \\
\hline Patentee Wins & 29 & $44.6 \%$ & 14 & $33.3 \%$ & 12 & $21.05 \%$ \\
\hline Insubstantial Differences Test & 55 & $37.9 \%$ & 44 & $38.3 \%$ & 50 & $32.7 \%$ \\
\hline Patentee Wins & 18 & $32.7 \%$ & 16 & $36.4 \%$ & 10 & $20.0 \%$ \\
\hline
\end{tabular}


Table 1. Comparisons Among Pre-, Mid-, and Post-Festo Datasets (cont.)

\begin{tabular}{|c|c|c|c|c|c|c|}
\hline & \multicolumn{2}{|c|}{ Pre-Festo } & \multicolumn{2}{|c|}{$\begin{array}{c}\text { Federal Circuit } \\
\text { Festo }\end{array}$} & \multicolumn{2}{|c|}{$\begin{array}{c}\text { Post-Supreme } \\
\text { Court Festo }\end{array}$} \\
\hline & Number & Percent & Number & Percent & Number & Percent \\
\hline & \multicolumn{6}{|c|}{ Cases at Federal Circuit by DOE Test Used (cont.) } \\
\hline More than One DOE Test & 37 & $25.5 \%$ & 42 & $36.5 \%$ & 47 & $30.7 \%$ \\
\hline Patentee Wins & 15 & $40.5 \%$ & 17 & $40.5 \%$ & 7 & $14.9 \%$ \\
\hline Dedication to Public Domain & 1 & $0.7 \%$ & 3 & $2.6 \%$ & 8 & $5.2 \%$ \\
\hline \multirow[t]{2}{*}{ Patentee Wins } & 0 & $0.0 \%$ & 1 & $33.3 \%$ & 2 & $25.0 \%$ \\
\hline & \multicolumn{6}{|c|}{ Cases by Small Entity Status } \\
\hline Small Entity & 70 & $48.3 \%$ & 60 & $52.2 \%$ & 68 & $44.4 \%$ \\
\hline \multirow[t]{2}{*}{ Patentee Wins } & 18 & $25.7 \%$ & 12 & $20.0 \%$ & 10 & $14.7 \%$ \\
\hline & \multicolumn{6}{|c|}{ Cases in Fourteen Technology Areas } \\
\hline Pharmaceutical & 9 & $6.2 \%$ & 3 & $2.6 \%$ & 15 & $9.8 \%$ \\
\hline Medical Devices & 20 & $13.8 \%$ & 18 & $15.7 \%$ & 24 & $15.7 \%$ \\
\hline Biotechnology & 5 & $3.5 \%$ & 1 & $0.9 \%$ & 5 & $3.3 \%$ \\
\hline Computer-Related & 30 & $20.7 \%$ & 33 & $28.7 \%$ & 47 & $30.7 \%$ \\
\hline Software & 24 & $16.6 \%$ & 28 & $24.4 \%$ & 39 & $25.5 \%$ \\
\hline Semiconductors & 2 & $1.9 \%$ & 0 & $0.0 \%$ & 5 & $3.3 \%$ \\
\hline Electronics & 19 & $13.1 \%$ & 15 & $13.0 \%$ & 47 & $30.7 \%$ \\
\hline Chemistry & 20 & $13.8 \%$ & 21 & $18.3 \%$ & 27 & $17.7 \%$ \\
\hline Mechanics & 105 & $72.4 \%$ & 68 & $59.1 \%$ & 82 & $53.6 \%$ \\
\hline Acoustics & 1 & $0.7 \%$ & 1 & $0.9 \%$ & 3 & $2.0 \%$ \\
\hline Optics & 8 & $5.5 \%$ & 13 & $11.3 \%$ & 26 & $17.0 \%$ \\
\hline Automotive-Related & 3 & $2.1 \%$ & 2 & $1.7 \%$ & 6 & $3.9 \%$ \\
\hline Energy-Related & 2 & $1.4 \%$ & 1 & $0.9 \%$ & 3 & $2.0 \%$ \\
\hline \multirow[t]{2}{*}{ Communications-Related } & 7 & $4.8 \%$ & 12 & $10.4 \%$ & 13 & $8.5 \%$ \\
\hline & \multicolumn{6}{|c|}{ Cases in Fourteen Technology Areas (Patentee Wins) } \\
\hline Pharmaceutical & 0 & $0.0 \%$ & 1 & $33.3 \%$ & 2 & $13.3 \%$ \\
\hline Medical Devices & 7 & $35.0 \%$ & 2 & $11.1 \%$ & 4 & $16.7 \%$ \\
\hline Biotechnology & 1 & $20.0 \%$ & 1 & $100.0 \%$ & 3 & $60.0 \%$ \\
\hline Computer-Related & 13 & $43.3 \%$ & 7 & $21.2 \%$ & 8 & $17.0 \%$ \\
\hline Software & 11 & $45.8 \%$ & 7 & $25.0 \%$ & 8 & $20.5 \%$ \\
\hline Semiconductors & 0 & $0.0 \%$ & 0 & $0.0 \%$ & 2 & $40.0 \%$ \\
\hline Electronics & 9 & $47.4 \%$ & 2 & $13.3 \%$ & 7 & $14.9 \%$ \\
\hline Chemistry & 5 & $25.0 \%$ & 4 & $19.1 \%$ & 7 & $25.9 \%$ \\
\hline Mechanics & 30 & $28.6 \%$ & 14 & $20.6 \%$ & 20 & $24.4 \%$ \\
\hline Acoustics & 0 & $0.0 \%$ & 1 & $100.0 \%$ & 1 & $33.3 \%$ \\
\hline Optics & 4 & $50.0 \%$ & 3 & $23.1 \%$ & 5 & $19.2 \%$ \\
\hline Automotive-Related & 0 & $0.0 \%$ & 0 & $0.0 \%$ & 2 & $33.3 \%$ \\
\hline Energy-Related & 0 & $0.0 \%$ & 0 & $0.0 \%$ & 0 & $0.0 \%$ \\
\hline Communications-Related & 2 & $28.6 \%$ & 2 & $16.7 \%$ & 1 & $7.7 \%$ \\
\hline
\end{tabular}


Table 2. Descriptive Statistics Across All Three Datasets

\begin{tabular}{|c|c|c|}
\hline & Number & Percent \\
\hline \multicolumn{3}{|c|}{ All Cases } \\
\hline Total Cases & 413 & \\
\hline Patentee Wins & 99 & $24.0 \%$ \\
\hline Patentee Wins in District Court & 66 & $30.6 \%$ \\
\hline Patentee Wins in Federal Circuit & 33 & $16.8 \%$ \\
\hline PHE Is an Issue & 156 & $37.8 \%$ \\
\hline Patentee Wins & 42 & $26.9 \%$ \\
\hline PHE Is an Issue in District Court & 74 & $34.1 \%$ \\
\hline Patentee Wins & 25 & $33.8 \%$ \\
\hline PHE Is an Issue in Federal Circuit & 82 & $41.8 \%$ \\
\hline Patentee Wins & 17 & $20.7 \%$ \\
\hline PHE Cases Based on Amendment & 103 & $66.0 \%$ \\
\hline Patentee Wins & 27 & $26.2 \%$ \\
\hline PHE Cases Based on Argument & 65 & $41.7 \%$ \\
\hline Patentee Wins & 18 & $27.7 \%$ \\
\hline \multicolumn{3}{|c|}{ Cases Won by Patentee by Stage of Litigation } \\
\hline Preliminary Injunction & 8 & $50.0 \%$ \\
\hline Summary Judgment Filed by Patentee & 4 & $13.8 \%$ \\
\hline Summary Judgment Filed by Accused Infringer & 68 & $22.3 \%$ \\
\hline Jury Trial & 8 & $38.1 \%$ \\
\hline Bench Trial & 7 & $24.1 \%$ \\
\hline JMOL Filed by Patentee & 3 & $75.0 \%$ \\
\hline JMOL Filed by Accused Infringer & 2 & $20.0 \%$ \\
\hline \multicolumn{3}{|c|}{ Cases Won by Patentee at Federal Circuit by Decision Type } \\
\hline Affirmance & 8 & $6.0 \%$ \\
\hline Reversal & 4 & $15.4 \%$ \\
\hline Remand & 21 & $63.6 \%$ \\
\hline Reversal and Remand & 25 & $42.4 \%$ \\
\hline \multicolumn{3}{|c|}{ All Cases by DOE Test Used } \\
\hline All Elements Rule & 151 & $36.6 \%$ \\
\hline Patentee Wins & 27 & $17.9 \%$ \\
\hline FWR Test & 164 & $39.7 \%$ \\
\hline Patentee Wins & 55 & $33.5 \%$ \\
\hline Insubstantial Differences Test & 149 & $36.1 \%$ \\
\hline Patentee Wins & 44 & $29.5 \%$ \\
\hline More than One DOE Test & 126 & $30.5 \%$ \\
\hline Patentee Wins & 39 & $31.0 \%$ \\
\hline Dedication to the Public Domain & 12 & $2.9 \%$ \\
\hline Patentee Wins & 3 & $25.0 \%$ \\
\hline MPF Claim Element Was at Issue & 75 & $18.2 \%$ \\
\hline Patentee Wins & 4 & $5.3 \%$ \\
\hline
\end{tabular}


February 2007] DEMISE OF THE DOCTRINE OF EQUIVALANTS

Table 2. Descriptive Statistics Across All Three Datasets (cont.)

\begin{tabular}{|c|c|c|}
\hline & Number & Percent \\
\hline \multicolumn{3}{|c|}{ Cases by Small Entity Status } \\
\hline Small Entity & 198 & $47.9 \%$ \\
\hline Patentee Wins & 40 & $20.2 \%$ \\
\hline \multicolumn{3}{|c|}{ Cases in Fourteen Technology Areas } \\
\hline Pharmaceutical & 27 & $6.5 \%$ \\
\hline Medical Devices & 62 & $15.0 \%$ \\
\hline Biotechnology & 11 & $2.7 \%$ \\
\hline Computer-Related & 110 & $26.6 \%$ \\
\hline Software & 91 & $22.0 \%$ \\
\hline Semiconductors & 7 & $1.7 \%$ \\
\hline Electronics & 81 & $19.6 \%$ \\
\hline Chemistry & 68 & $16.5 \%$ \\
\hline Mechanics & 255 & $61.7 \%$ \\
\hline Acoustics & 5 & $1.2 \%$ \\
\hline Optics & 47 & $11.4 \%$ \\
\hline Automotive-Related & 11 & $2.7 \%$ \\
\hline Energy-Related & 6 & $1.5 \%$ \\
\hline Communications-Related & 32 & $7.8 \%$ \\
\hline \multicolumn{3}{|c|}{ Cases in Fourteen Technology Areas (Patentee Wins) } \\
\hline Pharmaceutical & 3 & $11.1 \%$ \\
\hline Medical Devices & 18 & $29.0 \%$ \\
\hline Biotechnology & 5 & $45.5 \%$ \\
\hline Computer-Related & 28 & $25.5 \%$ \\
\hline Software & 26 & $28.6 \%$ \\
\hline Semiconductors & 2 & $28.6 \%$ \\
\hline Electronics & 18 & $22.2 \%$ \\
\hline Chemistry & 16 & $23.5 \%$ \\
\hline Mechanics & 64 & $25.1 \%$ \\
\hline Acoustics & 2 & $40.0 \%$ \\
\hline Optics & 12 & $25.5 \%$ \\
\hline Automotive-Related & 2 & $18.2 \%$ \\
\hline Energy-Related & 0 & $0.0 \%$ \\
\hline Communications-Related & 5 & $15.6 \%$ \\
\hline \multicolumn{3}{|c|}{ Published vs. Unpublished Dispositions } \\
\hline Published Cases & 245 & $59.3 \%$ \\
\hline Patentee Wins & 54 & $22.0 \%$ \\
\hline District Court Published Cases & 119 & $28.8 \%$ \\
\hline Patentee Wins & 32 & $26.9 \%$ \\
\hline Federal Circuit Published Cases & 125 & $30.3 \%$ \\
\hline Patentee Wins & 22 & $17.6 \%$ \\
\hline
\end{tabular}


Table 3. Descriptive Statistics in the Pre-Markman Dataset

\begin{tabular}{|c|c|c|}
\hline & Number & Percent \\
\hline \multicolumn{3}{|l|}{ All Cases } \\
\hline Total Cases & 95 & \\
\hline Patentee Wins & 38 & $40.0 \%$ \\
\hline Patentee Wins in District Court & 31 & $47.7 \%$ \\
\hline Patentee Wins in Federal Circuit & 7 & $23.3 \%$ \\
\hline PHE Is an Issue & 27 & $28.4 \%$ \\
\hline Patentee Wins & 11 & $40.7 \%$ \\
\hline PHE Is an Issue in District Court & 17 & $17.5 \%$ \\
\hline Patentee Wins & 7 & $41.2 \%$ \\
\hline PHE Is an Issue in Federal Circuit & 10 & $10.5 \%$ \\
\hline Patentee Wins & 3 & $30.0 \%$ \\
\hline PHE Cases Based on Amendment & 15 & $55.6 \%$ \\
\hline Patentee Wins & 6 & $40.0 \%$ \\
\hline PHE Cases Based on Argument & 17 & $62.9 \%$ \\
\hline Patentee Wins & 8 & $47.0 \%$ \\
\hline \multicolumn{3}{|c|}{ Cases Won by Patentee by Stage of Litigation } \\
\hline Preliminary Injunction & 3 & $43.0 \%$ \\
\hline Summary Judgment Filed by Patentee & 3 & $43.0 \%$ \\
\hline Summary Judgment Filed by Accused Infringer & 21 & $35.6 \%$ \\
\hline Jury Trial & 2 & $25.0 \%$ \\
\hline Bench Trial & 8 & $42.1 \%$ \\
\hline JMOL Filed by Patentee & 0 & $0.0 \%$ \\
\hline JMOL Filed by Accused Infringer & 1 & $25.0 \%$ \\
\hline \multicolumn{3}{|c|}{ Cases Won by Patentee at Federal Circuit by Decision Type } \\
\hline Affirmance & 3 & $15.7 \%$ \\
\hline Reversed & 4 & $36.4 \%$ \\
\hline Remand & 3 & $100.0 \%$ \\
\hline \multicolumn{3}{|c|}{ Cases by DOE Test Used } \\
\hline All Elements Rule & 17 & $17.9 \%$ \\
\hline FWR Test & 72 & $72.6 \%$ \\
\hline Insubstantial Differences Test & 6 & $6.3 \%$ \\
\hline Dedication to Public Domain & 0 & $0.0 \%$ \\
\hline \multicolumn{3}{|c|}{ Cases Won by Patentee by DOE Test Used } \\
\hline All Elements Rule & 4 & $23.5 \%$ \\
\hline FWR Test & 19 & $41.7 \%$ \\
\hline Insubstantial Differences Test & 2 & $33.0 \%$ \\
\hline Dedication to Public Domain & 0 & $0.0 \%$ \\
\hline
\end{tabular}

Abbreviations: DOE = Doctrine of Equivalents; PHE = Prosecution History Estoppel; $\mathrm{JMOL}=$ Judgement as a Matter of Law; FWR = Function-Way-Result. 